\title{
Reflecting on future research concerning the added value of FM
}

\author{
Jensen, Per Anker; van der Voordt, Theo; Coenen, Christian; Sarasoja, Anna-Liisa
}

Published in:

Facilities

Link to article, DOI:

10.1108/F-09-2012-0070

Publication date:

2014

Document Version

Early version, also known as pre-print

Link back to DTU Orbit

Citation (APA):

Jensen, P. A., van der Voordt, T., Coenen, C., \& Sarasoja, A-L. (2014). Reflecting on future research concerning the added value of FM. Facilities, 32(13/14), 856 - 870. https://doi.org/10.1108/F-09-2012-0070

\section{General rights}

Copyright and moral rights for the publications made accessible in the public portal are retained by the authors and/or other copyright owners and it is a condition of accessing publications that users recognise and abide by the legal requirements associated with these rights.

- Users may download and print one copy of any publication from the public portal for the purpose of private study or research.

- You may not further distribute the material or use it for any profit-making activity or commercial gain

- You may freely distribute the URL identifying the publication in the public portal

If you believe that this document breaches copyright please contact us providing details, and we will remove access to the work immediately and investigate your claim. 


\section{Emerald Insight}

\section{Facilities}

REFLECTING ON FUTURE RESEARCH CONCERNING THE ADDED VALUE OF FM:

Per Anker Jensen Theo van der Voordt Christian Coenen Anna-Liisa Sarasoja

\section{Article information:}

To cite this document:

Per Anker Jensen Theo van der Voordt Christian Coenen Anna-Liisa Sarasoja , (2014),"REFLECTING ON FUTURE RESEARCH CONCERNING THE ADDED VALUE OF FM", Facilities, Vol. 32 Iss 13/14 pp. -

Permanent link to this document:

http://dx.doi.org/10.1108/F-09-2012-0070

Downloaded on: 22 September 2014, At: 02:01 (PT)

References: this document contains references to 0 other documents.

To copy this document: permissions@emeraldinsight.com

\section{Users who downloaded this article also downloaded:}

Goksenin Inalhan, Per Anker Jensen, (2010),"The Facilities Management Value Map: a conceptual framework", Facilities, Vol. 28 Iss 3/4 pp. 175-188

Akarapong Katchamart, (2013),"Mapping value added positions in facilities management by using a product\#process matrix", Journal of Facilities Management, Vol. 11 Iss 3 pp. 226-252

Tomi Ventovuori, Tero Lehtonen, Anssi Salonen, Suvi Nenonen, (2007),"A review and classification of academic research in facilities management", Facilities, Vol. 25 Iss 5/6 pp. 227-237

Access to this document was granted through an Emerald subscription provided by 312821 []

\section{For Authors}

If you would like to write for this, or any other Emerald publication, then please use our Emerald for Authors service information about how to choose which publication to write for and submission guidelines are available for all. Please visit www. emeraldinsight. com/ authors for more information.

\section{About Emerald www.emeraldinsight.com}

Emerald is a global publisher linking research and practice to the benefit of society. The company manages a portfolio of more than 290 journals and over 2,350 books and book series volumes, as well as providing an extensive range of online products and additional customer resources and services.

Emerald is both COUNTER 4 and TRANSFER compliant. The organization is a partner of the Committee on Publication Ethics (COPE) and also works with Portico and the LOCKSS initiative for digital archive preservation. 


\section{Reflecting on future research concerning the added value of FM}

\section{INTRODUCTION AND BACKGROUND}

During the last decades the perception and application of Facilities Management has gradually shifted from primarily steering on cost reduction towards managing of facilities as a strategic resource to add value to the organisation and its stakeholders and to contribute to its overall performance. Researchers and opinion makers have argued for the need for FM to add value for many years. Price et al. (2011) for instance write: "While Becker et al. (1994) could distinguish business-driven and cost-driven workspace projects and show that the former delivered greater productivity than the latter, notional cost and planning efficiencies dominated FM practice... Unfortunately, as FM developed, and despite similar calls from other academic pioneers of the subject ...., the dominant thinking in FM remained concerned with judging claimed 'productivity' by what were actually indicators of efficiency." However, research has shown that FM practitioners in recent years increasingly have realised the need to add value and there are examples of development of methods to measure and document added value in FM practice (see for instance Jensen, 2010).

This change has been the background for the work in a EuroFM research group established in 2009. The main results are presented in the anthology "The Added Value of Facilities Management - Concepts, Findings and Perspectives" (Jensen et al., 2012a). The book shows why and how this shift occurred and how the supply of facilities and services can or should be aligned to the different interests and needs of various stakeholders. It connects concepts, theoretical frameworks, research data and measurement tools from different countries and different disciplines, including Facilities Management (FM), Corporate Real Estate 
Management (CREM), and Business to Business Marketing (B2B Marketing). The case studies explored different sectors such as offices, higher education, industry and health care. Much attention was paid to value adding management, performance measurement and Key Performance Indicators covering six different types of added value: use value (quality in relation to the needs and preferences of the users), customer/consumer/user value (the tradeoff between benefits and costs for these stakeholders), economic/financial/exchange value (the economic trade-off between costs and benefits), social value (e.g. supporting positive social interaction or reinforcing social identity), environmental value (Green FM, environmental impact of FM), and relationship value (e.g. getting high-quality services or experiencing a special treatment) (Jensen et al., 2012b).

The starting point for this international collaboration was the so-called FM Value Map (Jensen, 2010), that visualizes the links between input (resources), throughput (process), output (provisions) and outcomes, i.e. the impact of FM on the core business and the surroundings. The book ends up with many lessons learned, both from an academic and a practical point of view, and input for the future research agenda. The article builds on the results of this collaborative research and aims 1) to summarize main findings and further exploration regarding five interesting topics, and 2) to outline perspectives for future research and development of the added value of FM.

The need for further exploration of the added value of FM is supported by several future studies: IFMA Forecasts 2011 (IFMA, 2011), ISS Vision 2020 (ISS, 2011) and the Future of FM in the Nordic countries (Rasmussen et al., 2012). The most recent future study is based on the CRE\&FM Futures Forum established by Zurich Insurance Group Ltd., who organised a five day long international online crowd-sourcing event in the beginning of 2012. The final 
report (Hinks et al., 2012) concludes that CRE\&FM still has no objective way of evidencing the value that it brings to business. This is a fundamental blocker to CRE\&FM to be seen by the business as an asset rather than as a cost.

The next section of this paper provides an overview of important topics for further research that came the fore in the Anthology of the Added value of FM. After that follows a further elaboration of five main topics related to Corporate Strategy, FM Value Map, Sustainability and Corporate Social Responsibility, Branding, and Relationship Management.

\section{TOPICS FOR FUTURE FM RESEARCH}

When you ask 100 experts in FM or CREM to mention a top ten list of most important research topics to work on in the near future you will probably get 100 different answers. Even so, the lists will have much in common. Table 1 shows a top ten list that is based on recommendations for further research by the contributors to the book "The Added Value of Facilities Management" (Jensen et al., 2012a), priorities that came to the fore in foresight studies that were mentioned in the introduction part of this paper, the research agenda of Facility Management Netherlands (Thijssen et al., 2012), and suggestions from various European FM conferences.

Take in Table 1

The research topics refer both to FM-processes - throughput: by whom, for whom, how - and to resources (input), FM-provisions (output) and FM-impacts (outcomes) on society, clients, customers and end users. A key issue is how to incorporate added value of FM and value 
adding management in business strategies and business cases, in different sectors such as public and private organisations, offices, health care, education, industry, retail and leisure, and residential areas. Another key issue is how to cope with current trends such as a growing need for a more sustainable society, new worlds of working allowing people how, where, when and with whom they work (often in temporary network groups), the shift towards a demand driven organisation with an increased level of outsourcing - from operational tasks to integrated FM - and new FM concepts such as hospitality and branding by FM.

There is also a growing need for transparent business operations and evidence that objectives are met. A particular point of attention is how to balance the costs and benefits of FMinterventions, taking into account the needs, preferences and interests of different stakeholders, potential synergy and conflicts between other supporting units such as HRM, ICT, and Finance \& Control, and prerequisites regarding budget, time and regulations. Finally there is a need for a broad range of qualitative and quantitative methods for data-collection and data-analysis, including methods based on close interaction between researchers and practice like action research, participant observation, and narratives.

\section{A CLOSER LOOK AT FIVE TOPICS}

The following parts of the article will elaborate further on five topics:

1. Incorporation of added value of FM in corporate strategy

2. Further development and improvement of the FM Value Map

3. FM supporting Sustainability and Corporate Social Responsibility (CSR)

4. Branding 


\section{Relationship Management}

Figure 1 positions the five topics in the FM Value Matrix, which is an extension of a Research Grid included in Coenen et al. (2012a). The FM Value Map concerns the whole FM Value Matrix. The other four topics are related to a specific part of the FM Value Matrix.

Take in Figure 1

\section{Incorporation of added value of FM in corporate strategy}

According to the definition of FM in CEN (2006): "the integration of processes within an organisation to maintain and develop the agreed services", FM is not a goal in itself but a means "to support and improve the effectiveness of primary activities". The added value of FM can be defined as the trade-off between the benefits of FM and the costs and risks connected with achieving these benefits (Jensen et al., 2012c). The six types of added value that came to the fore in an analysis of over fifty definitions and descriptions of added value clearly show the multi-dimensionality of the added value concept, including a) a socialpsychological dimension referring to the needs and interests of all people involved, b) a business strategy dimension focusing on supporting the mission and vision of the organisation, its goals and objectives and its overall performance, c) an economic dimension i.e. an optimal ratio between financial benefits and costs, and d) a societal dimension regarding sustainability, corporate social responsibility, and branding. Performance includes various issues as well, such as health, safety and security, functionality, efficiency, work flow performance, and psychological, social, cultural and aesthetic performance. As such performance is an umbrella term for all concepts that refer to the success of a company and its activities. Widely used performance indicators showed to be efficiency and effectiveness, the 
former with a focus on input parameters such as capital (steering on cost reduction), space (optimizing use of space) and people, the latter with a focus on output parameters such as quality, satisfaction, health, safety, creativity, flexibility, profitability and sustainability. There is a strong need for an evidence based conceptual framework that connects different types of value to FM interventions and to test if, how and when these value dimensions are incorporated in decision making processes on strategic, tactical and operational level, and by whom: top management, middle management, FM and CREM staff and other supporting units such as HRM, Finance \& Control and IT-departments. In order to disentangle the complexity of adding value by FM and to be able to incorporate adding value management in daily practice, further research is needed into many issues:

- What can different disciplines such as architecture, engineering, business administration, marketing, psychology, economics etc. contribute to such conceptual frameworks?

- How can theories of coordination contribute to the understanding and management of governance structures and alignment between FM and corporate strategies?

- What are generic aspects of adding value and which aspects should differentiate between different areas, different types of organisations and different contexts?

- What are the main drivers in value adding management?

- Which value dimensions are prioritized by shareholders and other stakeholders such as local authorities and communities, managers, investors, developers, designers, clients, customers, end users and visitors?

- Which value dimensions lead to synergy and how do organisations cope with conflicting values?

- Who is involved in decision making on adding value by FM and value adding management, strategic, tactical, and operational, and in which phases of FM processes? 
- Which KPIs are used or could be used on strategic, tactical and operational level, regarding the real estate portfolio, buildings, units, places, facilities and services?

- Which considerations are important in selecting and prioritizing KPIs to be used in performance management policies? Who is or should be involved in this selection?

- How do organisations cope with the dilemma between what can be measured and what really matters?

- How can complex cause-effect relationships be disentangled and measured?

\section{Further development and improvement of the FM Value Map}

The FM Value Map was developed by Per Anker Jensen, based on a large number of case studies from the research project "FM Best Practice in the Nordic Countries" (Jensen et al. 2008) and from the NordicFM workgroup "Highlight the Added Values for the Core Business Provided by Facilities Management” (Jensen and Malmstrøm, 2012). The FM Value Map has been presented in an earlier article in Facilities (Jensen, 2010).

The EuroFM research group has identified a number of strengths and weaknesses of the present FM Value Map and opportunities for further exploration and improvement. A strong point is the holistic view of FM and its possible impacts on both the core business and surroundings, by including benefits for all relevant stakeholders and not just shareholders. It builds on existing models and approaches such as system thinking and the Balanced Scorecard (Kaplan and Norton, 2001). The concepts and definitions are aligned to the new European FM standards (EN 15221). The FM Value Map is seen as a useful tool to analyse cases from practice and to show the different ways they create added value. 
In the book the FM Value Map (Jensen et al., 2008) is compared with 3 recent models of adding value based on CREM (De Vries et al., 2008, Lindholm and Aaltonen, 2011 and Den Heijer, 2011), see Table 2.All four models include adding value parameters, which can be grouped under the headings people, process and economy in relation to core business. Similar to the FM Value Map, the two most recent CREM based models also include parameters related to surroundings - particularly in relation to sustainability. The structure of the FM Value Map differs basically from the three CREM based models by including a clear separation between FM and core business and inclusion of specific FM processes.

Take in Table 2

The FM Value Map represents a resource based view with a main focus on provision of value (supply side) rather than an orientation on the core business strategy and the perception of value by the clients, customers and end users (demand side). Much attention is being paid to the internal processes of FM and less to the processes between FM and its stakeholders. Although the FM Value Map can be applied at a strategic, tactical and operational level, it is not completely clear how to use the FM Value Map on these different levels. The value map is also fairly static. It can be used to create an overview and basic understanding for academic purposes and to be used as a framework for developing strategies for adding value, but it is not action oriented.

Much work still has to be done to further test and develop the FM Value Map in practice with respect to the impact of FM products and FM processes, its applicability in decision making processes and to define and measure the outcomes of FM decisions and interventions in a reliable and valid way. There is also a need to supplement the value map with a broader 
management concept for adding value of FM. A proposal for such a concept called Value Adding Management (Jensen and Katchamart, 2012) is presented in the book.

\section{FM supporting Sustainability and Corporate Social Responsibility}

Corporate sustainability has been the subject of research interest in the social sciences since the mid-1900s while corporate Social Responsibility (CSR) has existed as a term for over 70 years. In recent years sustainability and CSR have become increasingly important topics in private and public organisations. Companies have realized that every decision has an impact on shareholders, personnel, clients and the surrounding communities. It is an area where FM is expected to have great potential to contribute and thereby add value to corporations. One of the most obvious areas of how FM can contribute to sustainability and CSR is the environmental aspect. Buildings and facilities contribute as much as one third of total global greenhouse gas emissions. The building sector has the most potential for delivering significant and cost-effective greenhouse gas emission reductions in western economies (UNEP, 2009). Less recognized is that life cycle assessments have shown that over $80 \%$ of greenhouse gas emissions take place during the use phase of buildings (Junnila and Hovarth, 2003; Junnila et al, 2006; Scheuer et al., 2003).

Ventovuori et al. (2012) found that Northern European companies do not fully recognize the sustainability impacts of their facilities and real estates and have not aligned their FM and Corporate Real Estate Strategies with the company sustainability objectives. There is some evidence on how single sustainability practices such as green building certifications improve company environmental performance and as such create added value, and how green buildings affect rents, values and real estate investments (e.g. Miller et al 2008; Fuerst and McAllister 2009; Falkenbach et al. 2010). However, less attention has been paid to how to 
build successful sustainable FM strategies. Further research is needed to provide best practices and scientific based evidence to operationalize the the environmental value of FM and the benefit and sacrifice dimensions.

Another area of CSR and sustainability where FM can have an important role regards the social aspect. People are spending most of their day-time at offices, stores, factories and public spaces. Facilities can have a huge influence on employee well-being, satisfaction and even recruiting. This can comprise community use of corporate facilities, providing jobs for people with physical disabilities, and securing proper conditions for employees in the FM supply chain.

Traditionally CSR activities have mostly been of philanthropic nature without any specific relation to corporations' core business. Such philanthropic activities have in recent years been criticized for having limited impact. Porter and Kramer (2006) argue for an alternative concept called "Strategic CSR", where the CSR activities are closer related to the corporate strategy and to the core business activities. Porter and Kramer (2011) furthermore developed the concept "Creating Shared Value" (CSV), where corporations engage in collaboration with local communities to create developments of mutual benefits both for the corporations' business activities and for the communities. So far some literature has been published on shared value creation, but no applications or models for facilities or FM processes have been presented.

\section{Branding}

Due to a globalizing and extremely competitive society where product differentiation is no longer sufficient to maintain a good market position, the value of a company and its products 
depends more and more on adequate branding (Khanna et al., forthcoming). A corporate brand is formed by all experiences and perceptions that people relate to a company. Corporate branding is believed to create, communicate and deliver value to customers, benefit organizational performance and support competitive advantage (Balmer \& Gray, 2000). The role of real estate in communicating brand values to internal and external stakeholders is recognized as well (De Jonge, 2002; Krumm \& De Vries, 2003; Koppels et al., 2009; AppelMeulenbroek et al., 2010; Khanna et al., forthcoming). Myerson and Turner (1998) use the term "Narrative offices" to refer to (office) buildings that tell a story about brand values and environments that are used as a substantive tool in brand differentiation. "Facilities branding management" by using FM and CREM to support a positive corporate image is quite complex, due to our limited understanding of the influence of FM on corporate image.

In a recent study, in-depth interviews with seven multinationals showed that they all incorporate brand values in their location strategy, portfolio management, building strategy, and workplace strategy (Khanna et al., forthcoming). Widely used brand values include sustainability, reliability, innovation, people-orientation, and transparency. Regarding location strategy most organisations translate sustainability as a brand value through the proximity to public transport i.e. a train station, and centralization vs. decentralization. In the building strategy the focus on sustainability is visible in energy management programs, a growing use of video conferencing facilities, application of new concepts such as Cradle-to-Cradle, optimizing the footprint to achieve $\mathrm{CO}_{2}$ reduction, the use of sustainable products like LEDlighting and LED-sensors and the use of environmentally friendly materials and plants. In workplace strategies sustainability is usually connected to similar issues and to new ways of working with desk-sharing (to reduce the footprint) and teleworking (to reduce mobility). Measures to communicate the brand value reliability are closely linked to continuity (e.g. life 
span use of existing buildings) and smart and efficient use of capital and other resources (e.g. adaptive reuse of vacant buildings). Companies considering innovation as one of their brand value often link innovation to technological developments in their core businesses, for instance Philips, Vodafone and Logica. In the location strategy, 'innovation' is usually depicted by choosing the location in regions where talented labor is concentrated. One of the interviewed companies' brand values is "connecting people". This has been translated in a location in the central business district, with a high exposure to the outside world and customers, visible from the highway and served by two train stations. Transparency is usually translated in the use of glass, flexible working in open settings, atria and voids. In addition, real estate and other facilities are also used to support the distinctiveness and reputation of the company. For instance by choosing a high rise building as visible element in the skyline of the city, the use of a huge reception desk with the back wall showing the company logo, global guidelines for workplace design to induce an enterprise identity, or a historic showcase and banners showing the large products range of the company to the customers.

In addition to current research findings there is still a need for further study in-depth of how FM and CREM can influence corporate image and be used for marketing purposes and which lessons can be learned from research fields such as architecture, marketing, and behavioural sciences. Interesting questions for future research are for instance:

- Which values are or can be expressed by facilities, how?

- Does the corporate image as perceived by different stakeholders and the general public correspond with the corporate identity i.e. the image that the organisations want to achieve and the brand values they want to express? 
- What are the costs and benefits of FM interventions, from the perspectives of different stakeholders, in different areas such as offices, retail and leisure, health care, education and industry?

- Which frameworks and tools are available or should be developed to support facilities branding management?

\section{Relationship Management}

Due to the fact that the customer is the final arbiter of value, it is incumbent on the service provider and customer to align themselves on value expectations (Hinks et al., 2012d). Generally speaking, customers evaluate not only the quality of the service provided, but also the quality of the entire relationship (Bruhn and Georgi, 2006; Ellison and Flowers, 2012). Thus, establishing long-term relationships between providers and customers can be considered essential for successful FM. As Jensen et al. (2012c) have recently pointed out, good relationship management is shown to be as important as delivering the agreed services. In their current RICS research report, Ware and Carder (2012, p. 9) point out, "that the critical skills needed for future leaders focus primarily around collaboration, interpersonal relationships, (...), and managing service providers." With regards to a successful relationship management in FM, Hinks and his co-authors ask in their latest study about the future of CRE and FM: "What are the characteristics of the most meaningful and creative partnerships and context(s) in which they will most likely succeed?" (Hinks et al., 2012c, p. 25).

The research gap in the field of relationship management in FM appears rather large. Only little research has been conducted in this field so far (for exceptions see e.g. Hoots, 2005; Lehtonen, 2006; Coenen et al., 2012b). The current RICS research report presents a complex web of relationships in which "the Head of FM is at the centre (...) between the senior 
executives, strategic business units, IT, HR, RE, and (....) service providers as well.” (Ware \& Carder, 2102, p. 21). The two authors examine critical relationships between FM and other organizational functions and outside service providers. They identify six gaps that appear within this web of relationships. Gap 1 relates to developing tools to translate corporate strategy into FM strategy. Gap 2 is about developing effective tools to translate the strategy of strategic business units into FM strategy. Gap 3 is about understanding and translating financial strategies. Gap 4 is about building relationships between RE/FM, IT and HR, to create a workplace strategy. Gap 5 is about bridging the relationship between workplace strategy and design/delivery projects. Finally, Gap 6 deals with the alignment of the FM supply chain with FM strategy, and with the organization as a whole (Ware \& Carder, 2012).

The following future fields of research with regards to relationship value in FM can be identified:

- Differentiating perception of key stakeholders in regards to relationship value of FM According to Hinks et al., 2012b, p. 20, future research should include issues of differentiating between value for clients, customers and end users. Thus, the above mentioned network of relationships can be considered as network of internal and external stakeholders, who perceive value differently.

\section{- Categorizing various benefit and sacrifice dimensions of relationship value of FM}

Which categories of benefits and sacrifices make up the value from the client's, customer's and/or end user's perspective? Docertain benefit categories enable to (over)compensate one or more sacrifice categories?

- Identifying important driving forces of relationship value of FM

What impacts the value perception of each stakeholder group? How important is each category in comparison to the overall value perception? 
- Detecting relationship encounters with different relevance to FM

A relationship consists of various sequential encounters that shape the overall perception of the whole relationship between the FM-provider and its stakeholders. What are the most important relationship encounters between FM and its stakeholders?

\section{- Exploring the relationship lifecycle of FM}

How does a relationship differ in regards to trust and commitment in the course of the relationship during initialization, maturity, stagnation, and recovery phase? What drives the different value perceptions during these various lifecycle phases?

- Establishing valid measurement tools to evaluate relationship value of FM

A first approach for operationalizing relationship value in FM has been made by Coenen et al., 2012b, and Cui, 2013). There is a need for additional empirical evidence-based work for validating this measurement tool.

- Acknowledging the co-creation paradigm of relationship value of FM

Especially, the co-creation of value as pointed out by Porter and Kramer (2011) and Alexander (2012) can be expected to be a vital point of research in the future.

- Identifying relationship value's role compared to other value dimensions of FM

Future research should identify the holistic role relationship value plays in comparison to other value dimensions and find out what the conceptual framework of these value dimensions consists of.

\section{CONCLUSION}

This article shows that in spite of many available research findings we still need to learn more about the added value of FM. There is still a strong need for conceptual models that connect 
the different types of value to FM interventions and to test if, how and when these values are or could be incorporated in decision making processes on strategic, tactical and operational level, by whom, and how to cope with conflicting values and with the dilemma between what can be measured and what really matters. The FM Value Map was an important starting point for the collaborative research on which this paper builds on. It has been thoroughly evaluated and compared with other recent models. It turned out that there is a need to supplement the value map with a broader management concept for adding value of FM and a more action oriented approach. Sustainability and CSR is an area where FM is expected to have great potential to contribute and thereby add value to corporations. Future research on sustainable FM should be taking more strategic focus and should identify practices and ways which provide the greatest sustainability value instead of sub-optimisation or green-washing. The on-going shift from philanthropic towards more strategic CSR and Creating Shared Value makes it more relevant for FM to contribute to the activities, and thereby play a more strategic role in their organisation. Understanding and modelling the FM processes from the shared value perspective will be interesting research topic for the future.

There is also a clear research potential to further study in-depth how FM and CREM can influence the corporate image and be used for marketing purposes, for instance by a further exploration of the costs and benefits of FM interventions from the perspectives of different stakeholders, on different levels, and in different areas. Finally, good relationship management has been shown to be as important as delivering the agreed services. Thus, FM can be acknowledged as a relationship management discipline, including all challenges that derive from being at the centre of a web of relationships between the senior executives, strategic business units, IT, HR, RE and external service providers. Only little research has been conducted in this field so far. 


\section{REFERENCES}

Alexander, K. (2012), "Co-creation of value in FM", In Alexander, K. and Price, I. (Eds.), Managing Organizational Ecologies - Space, Management, and Organizations, Taylor \& Francis, New York.

Appel-Meulenbroek, H.A.J.A., Havermans, D.W.Q., Janssen, I.I., and Kempen, A.J.M. van (2010), "Corporate branding: an exploration of the influence of CRE". Journal of Corporate Real Estate, 12(1), pp. 47-59.

Balmer, J.M.T. and Gray, E.R. (2000), “Corporate identity and corporate communications: creating a competitive advantage”. Industrial and Commercial Training, 32 (7), 256-262.

Bruhn, M. and Georgi, D. (2006), Services Marketing - Managing the Service Value Chain, Pearson Education, Harlow.

CEN (2006), Facility Management - Part 1: Terms and definitions, EN15221-1.

Coenen, C. Alexander, K., and Kok, H. (2012a), "FM as a Value Network: Exploring Relationships amongst Key FM Stakeholders”. Chapter 5 in Jensen et al. (2012a), pp. 75-91. Coenen, C. von Felten, D., and Waldburger, D. (2012b), "Beyond Financial Performance: Capturing Relationship Value in FM". Chapter 7 in Jensen et al. (2012a), pp. 105-122.

Cui, Y. (2013), Relationship Value in FM - A customer perspective. MSc-thesis. Institute of Facility Management, Zurich University of Applied Sciences.

De Jonge, H. (2002), “De ontwikkeling van Corporate Real Estate Management”. Real Estate Magazine, 22, 8-12.

De Vries, J., De Jonge, H. and Van der Voordt, D.J.M. (2008), "Impact of real estate interventions on organisational performance", Journal of Corporate Real Estate, Vol. 10, No.

3, pp. 208-223. 
Den Heijer, A. (2011), Managing the university campus - Information to support real estate decisions. PhD thesis. Eburon Academic Publishers, Delft.

Ellison, I. and Flowers, J. (2012), "Ecologies in existence: boundaries, relationships and dominant narratives", In Alexander, K. and Price, I. (Eds.), Managing Organizational Ecologies - Space, Management, and Organizations, Taylor \& Francis, New York

Falkenbach, H., Lindholm, A-L. and Schleich, H. (2010), “Environmental Sustainability:

Drivers for the Real Estate Investor”, Journal of Real Estate Literature, 18(2), pp. 203-223.

Hatch, M.J. and Schultz, M. (2003), "Bringing the corporation into corporate branding". European Journal of Marketing, Vol. 37, pp. 1041-1064.

Hinks, J., Varcoe, B. and the Zurich CRE\&FM team (2012a): CRE\&FM Futures Forum. Final report, June 2012.

Hinks, J., Lopinksi, R., and Hendricks, L. (2012b), Customer Service. Chapter 03 in Hinks et al. (2012), pp. 18-20.

Hinks, J., Schumacher, R., and Lerner, B. (2012c), Partnerships. Chapter 06 in Hinks et al. (2012), pp. 25-27.

Hinks, J., Wright, P., and Halford-Maw, W. (2012d), Value-Based Pricing. Chapter 08 in Hinks et al. (2012), pp. 31-33.

Hoots, M. (2005), “Customer relationship management for facility managers", Journal of Facilities Management, Vol. 3, No. 4, pp. 346 - 361.

IFMA (2011), Exploring the Current Trends and Future Outlook for Facility Management. Facility Management Forecast 2011, International Facility Management Association, May 2011.

ISS (2011), ISS 2020 Vision - Scenarios for the future of the Global Facility Management Industry. White Book, ISS World Services A/S, Copenhagen, October 2011. 
Jensen, P.A. (2010), "The Facilities Management Value Map: a conceptual framework". Facilities, Vol. 28, No. 3/4, pp. 175-188.

Jensen, P.A. and Katchamart, A. (2012), Value Adding Management: A Concept and a Case. Chapter 10 in Jensen et al. (2012), pp. 164-176.

Jensen, P.A. and Malmstrøm, O.E. (2012), Highlighting the Added Value for the Core Business provided by Facilities Management. Report. NordicFM (www.nordicfm.eu).

Jensen, P.A., Nielsen, K. and Nielsen, S.B. (2008), Facilities Management Best Practice in the Nordic Countries - 36 cases. Centre for Facilities Management - Realdania Research, DTU Management Engineering. Technical University of Denmark.

Jensen, P., van der Voordt, T. and Coenen, C. (Eds.) (2012a), The Added Value of Facilities Management: Concept, Findings and Perspectives. Centre for Facilities Management Realdania Research, DTU Management Engineering, and Polyteknisk Forlag, May 2012. Jensen, P., van der Voordt, T., Coenen, C. and Sarasoja, A.-L. (2012b), Comparisons and Lessons Learned. Chapter 17 in Jensen et al. (2012a), pp. 268-292.

Jensen, P., van der Voordt, T., Coenen, C., von Felten, D., Lindholm, A-L., Balslev Nielsen, S., Riratanaphong, C. and Pfenninger, M. (2012c), "In Search for the Added Value of FM: What we know and what we need to learn", Facilities, Vol. 30, No. 5/6.

Junnila, S. (2007), "The potential effect of end-users on energy conservation in office buildings", Facilities, Vol. 25 No. 7/2, pp. 329-339.

Junnila, S. and Horvath, A. (2003), "Life-Cycle Environmental Effects of an Office Building”, Journal of Infrastructure System, Vol. 9 No. 4, pp. 157-166.

Junnila, S, Horvath, A, and Guggemos, A. A. (2006), "Life-Cycle Assessment of Office Buildings in Europe and the United States", Journal of Infrastructure Systems, Vol. 12 No. 1, pp. 10-17. 
Kaplan, R.S. and Norton, D.P. (1992), "The balanced scorecard - Measures that drive performance". Harvard Business Review, January-February.

Kaplan, R.S. and Norton, D.P. (2001), "Having Trouble with Your Strategy? Then Map It". Harvard Business Review, January-February 2001.

Khanna, C., Van der Voordt, T.J.M. and Koppels, P.W. (2013), “Corporate Real Estate mirrors Brand: A conceptual framework and practical applications”. Journal of Corporate Real Estate. Forthcoming.

Koppels, P.W., Remøy, H.T. and De Jonge, H. (2009). "The economic value of image", PropertyNL Research Quarterly, Vol. 8 nr. 3, 31-38.

Krumm, P. J. \& De Vries, J.C. (2003),"Value Creation through management of real estate”. Journal of Property Investment and Finance, 21, 61-72.

Lehtonen, T. (2006), "Collaborative relationships in facility services", Leadershin \& Organization Development Journal, Vol. 27, No. 6, pp. 449-464.

Lindholm, A-L, Gibler, K. M., Leväinen K. I. (2006), "Modelling the Value-Adding Attributes of Real Estate to the Wealth Maximization of the Firm", Journal of Real Estate Research, Vol. 28. No. 4, pp. 445-475.

Lindholm, A.-L. and Aaltonen, A. (2011), “Green FM as an adding value element for the core business." CFM's Nordic Conference 22-23 August 2011. Centre for Facilities Management - Realdania Research, DTU Management Engineering. Technical University of Denmark.

Miller, N., Spivey, J. and Florance, A. (2008) Does Green Pay Off? Journal of Real Estate Portfolio Management, 14, pp. 385-401.

Myerson, J. and Turner, G. (1998), The Workspace. New Culture: Office Design as a Catalyst for Change. UK.: Gower. 
Porter, M. E. and Kramer, M. R. (2006), "Strategy and Society: The Link between Competitive Advantage and Corporate Social Responsibility”, Harvard Business Review, December 2006.

Porter, M. and Kramer, (2011), “The Big Idea: Creating Shared Value”, Harvard Business Review, No. 1, January/February 2011.

Price, I., Beard, C., Ellison, I. and Matzdorf, F (2011), Triple bottom line space: Productivity paradoxes in FM. $10^{\text {th }}$ EuroFM Research Symposium, EFMC2011, Vienna.

Rasmussen, B., Dannemand Andersen, P. and Jensen, P.A. (2012), Foresight on Facilities Management in the Nordic Countries - Proposal for a Common Research Agenda. Research Report 2.2012. Centre for Facilities Management - Realdania Research, Technical University of Denmark.

Scheuer, C., Keoleian, G., Reppe, P. (2003), “Life cycle energy and environmental performance of a new university building: modeling challenges and design implications", Energy and Buildings, Vol. 35 No. 10, pp. 1049-1064.

Thijssen, T., Van der Voordt, T., and Mobach, M. (2012), "Facility Management research in the Netherlands". European FM Insight. Issue 21, June 2012, pp. 9-10.

UNEP (2009), Buildings and Climate Change - Summary for decision makers. United Nations Environment Programme.

Van Loon, S. (2005), Form follows Identity. MSc-thesis. Faculty of Architecture, Delft University of Technology (in Dutch).

Ware, J. and Carder, P. (2012), Raising the Bar: Enhancing the Strategic Role of Facilities Management - RICS Research Report, London, November 2012.

Ventovuori, T., Tuomela, A., Sarasoja, A-L,, Andelin, M .(2012). The role of Real Estate in Corporate Resposbility -Evidence from Northern European Companies, A paper presented at ARES conference, St. Petersburg, Fl, US, April, 2012. 
Zeithaml, V. (1988), "Consumer Perceptions of Price, Quality, and Value: A Means-End Model and Synthesis of Evidence", Journal of Marketing, Vol. 52, No. 3, pp. 2-22.

(C) Emerald Group Publishing Limited

This is a pre-print of a paper and is subject to change before publication. This pre-print is made available with the understanding that it will not be reproduced or stored in a retrieval system without the permission of Emerald Group Publishing Limited. 
Table 1: Ten important research topics

- Methodologies for FM becoming a critical strategic management tool linking FM to the organisation's core business strategy and value adding management.

- Governance structures for FM to secure the alignment between FM and core business, on strategic, tactical and operational level.

- Ways to contribute to the health and wellbeing of building occupants and as such benefiting efficiency, productivity and profitability.

- The impact of the ever changing context such as globalisation, demographic trends, economy (credit crunch; labour market), technology and politics on adding value by FM.

- Corporate Social Responsibility.

- Sustainability: Green FM, life cycle management, measurement methods.

- How to cope with the reversal from the supply chain into a more customer oriented one and issues such as experience value of FM, branding and hospitality

- Stakeholder's perceptions of value and relationships.

- Methods to measure hard and soft aspects of performance.

- Methods to analyse and visualise adding value by FM. 
Figure 1: FM Value Matrix with topic 1-5

\begin{tabular}{|l|c|c|c|c|}
\hline \multicolumn{1}{|c|}{ Relationship } & $\begin{array}{c}\text { Company }<> \\
\text { Society }\end{array}$ & $\begin{array}{c}\text { FM }<> \\
\text { Client }\end{array}$ & $\begin{array}{c}\text { FM }<> \\
\text { Customer }\end{array}$ & \multicolumn{1}{c|}{$\begin{array}{c}\text { FM }<> \\
\text { End user }\end{array}$} \\
\hline Ualue dimension & $\begin{array}{c}\text { Topic } 3 \\
\text { Sustainabilit } \\
\text { y and CSR }\end{array}$ & $\begin{array}{c}\text { Topic } 1 \\
\text { Corporate } \\
\text { Strategy }\end{array}$ & Topic 2 & FM Value Map \\
\hline Economical value & Environmental value & $\begin{array}{c}\text { Topic } 4 \\
\text { Branding }\end{array}$ & & Topic 5 Relationship Management \\
\hline Social value & & & \\
\hline Relationship value & & & \\
\hline
\end{tabular}


Table 2: Comparison of added value parameters in four models

\begin{tabular}{|c|c|c|c|c|}
\hline & $\begin{array}{l}\text { De Vries } \\
\text { et al. , } 2008\end{array}$ & $\begin{array}{l}\text { Jensen et al., } \\
2008\end{array}$ & $\begin{array}{l}\text { Lindholm and Aaltonen, } \\
2011\end{array}$ & Den Heijer, 2011 \\
\hline \multicolumn{5}{|l|}{ Core business } \\
\hline People & $\begin{array}{l}\text { Image } \\
\text { Culture } \\
\text { Satisfaction }\end{array}$ & $\begin{array}{l}\text { Satisfaction } \\
\text { Culture }\end{array}$ & $\begin{array}{l}\text { Increase employee } \\
\text { satisfaction }\end{array}$ & $\begin{array}{l}\text { Increasing user satisfaction } \\
\text { Supporting image } \\
\text { Supporting culture }\end{array}$ \\
\hline Process & $\begin{array}{l}\text { Production } \\
\text { Flexibility } \\
\text { Innovation }\end{array}$ & $\begin{array}{l}\text { Productivity } \\
\text { Reliability } \\
\text { Adaptability }\end{array}$ & $\begin{array}{l}\text { Increase innovation } \\
\text { Increase productivity } \\
\text { Increase flexibility }\end{array}$ & $\begin{array}{l}\text { Increasing flexibility } \\
\text { Supporting user activities } \\
\text { Improving quality of place } \\
\text { Stimulating innovation } \\
\text { Stimulating collaboration }\end{array}$ \\
\hline Economy & $\begin{array}{l}\text { Cost } \\
\text { Possibility to } \\
\text { finance } \\
\text { Risk control }\end{array}$ & Cost & $\begin{array}{l}\text { Increase value of assets } \\
\text { Promote marketing and sale } \\
\text { Reduce cost }\end{array}$ & $\begin{array}{l}\text { Controlling risk } \\
\text { Increasing real estate value } \\
\text { Decreasing cost }\end{array}$ \\
\hline Surroundings & & $\begin{array}{l}\text { Economical } \\
\text { Social } \\
\text { Spatial } \\
\text { Environmental }\end{array}$ & $\begin{array}{l}\text { Supporting environmental } \\
\text { sustainability }\end{array}$ & Reducing the footprint \\
\hline
\end{tabular}

(c) Emerald Group Publishing Limited

This is a pre-print of a paper and is subject to change before publication. This pre-print is made available with the understanding that it will not be reproduced or stored in a retrieval system without the permission of Emerald Group Publishing Limited. 